\title{
The role of quantity surveyors in public-private partnerships in South Africa
}

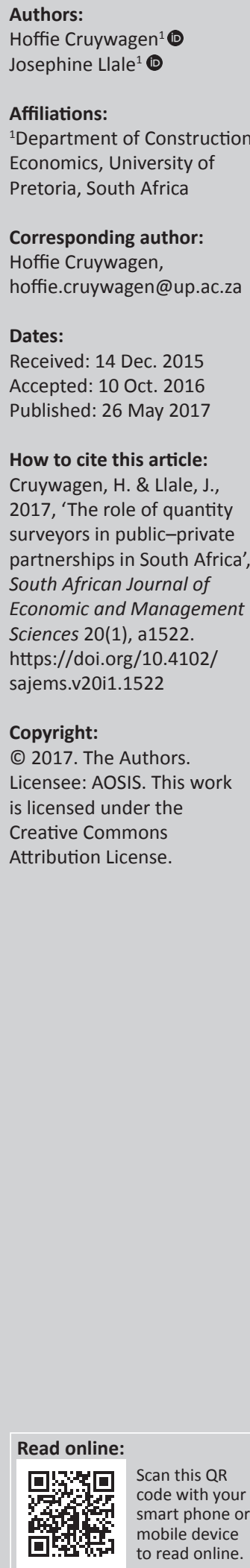

Background: Quantity surveyors play an important role in providing cost and contractual advice in the built environment. This article seeks to investigate the current extent of their involvement in public-private partnerships (PPPs) in South Africa.

Aim: The study intends to establish factors that influence quantity surveyors' participation in PPPs.

Methodology: A mixed-methods research approach was followed by firstly conducting a survey amongst South African quantity surveyors in order to determine their level of participation in PPPs. For triangulation purposes, a case study was also conducted.

Results: The results of the research show that, although quantity surveyors have the corresponding skills and competencies required in a PPP project, their current involvement in PPPs in South Africa is limited and that there is a greater role they can play in future.

Conclusion: Quantity surveyors are uniquely positioned to play a bigger role in the implementation of PPPs in South Africa.

\section{Introduction}

The quantity surveying profession is often regarded as an obscure profession. Many people often confuse it with land surveying (Ajalekoko 2004). In spite of its obscurity, the profession has been in existence for many centuries. Its value to society is immeasurable. The following is stated in the Bible, in the gospel of Luke 14:28, 'Suppose one of you wants to build a tower. Will he not first sit down and estimate the cost to see if he has money to complete it?' (Bible 2009).

The term 'quantity surveying' was first used in the United Kingdom (UK) in 1859 and is still widely used in many other commonwealth countries (Association of South African Quantity Surveyors [ASAQS] 2014). Other countries use different titles such as 'construction economists', 'value engineers' or 'cost engineers' (Drake 1995). As the quantity surveying profession in South Africa has its roots in the UK, it is important to compare factors that have influenced its survival and evolution over the years in both countries to establish how the profession can position itself to continue to add value to the society in future.

\section{Research questions}

In order to determine quantity surveyors' current and future possible role in public-private partnerships (PPPs), a survey and a case study were conducted. The aim of the research instruments was multi-pronged and sought to determine:

- By quantity, how many quantity surveyors are currently involved in PPPs?

- How familiar are quantity surveyors with PPPs?

- What are the factors that influence quantity surveyors to participate in PPPs?

- What perceptions have quantity surveyors regarding their education and training and how their education or perception thereof determines their participation in PPPs?

- What is the value of further education in the non-traditional role of quantity surveyors?

- What are the current role players', such as property developers and government officials, views regarding the services provided by quantity surveyors in PPPs?

\section{Literature survey}

PPP is one of the catalysts to the evolution of the quantity surveying profession in the UK (Cartlidge 2006). Quantity surveyors in the UK have been able to transfer their skills and competencies to PPP projects. In South Africa, the profession of quantity surveying, as that of their British counterparts, 
has come a long way since the arrival of the first quantity surveyors in South Africa in 1896 (ASAQS 2009). Currently, South African quantity surveyors play an important role in the local built environment industry and most of the private quantity surveying firms in South Africa focus on the traditional functions of quantity surveying such as estimating and cost advice, advice on tendering and contractual arrangements, financial control over contracts, project closeout and dispute resolution (ASAQS 2014). The abovementioned functions can be executed in either the commercial or in civil, mining and infrastructure projects.

PPPs in South Africa are still in their infancy (as discussed later in the article) and currently the Department of Public Works (DPW) (1997) is the custodian of public infrastructure in South Africa. Quantity surveyors are regarded as cost-andcontract specialists in the built environment and their role in the provision of infrastructural projects cannot be overlooked. It is, therefore, important to investigate their role in PPPs, and hence the research questions that were stated in the section 'Research questions'.

The theories that underpin PPPs fall broadly into three main categories (Mouraviev \& Kakabadse 2012):

- a partnership as a policy tool

- a PPP as an organisational and financial arrangement

- PPP performance, risk allocation and critical success factors.

There is no universal definition of a PPP (Mouraviev \& Kakabadse 2012). Grimsley and Lewis (in Mouraviev \& Kakabadse 2012) define a PPP as:
....an agreement where the public sector enters into a long-term contractual agreement with private sector entities for the construction or management of public sector infrastructure facilities by the private sector entity, or the provision of services (using infrastructure facilities) by the private sector entity to the community - on behalf of a public sector entity.

PPPs are often confused with privatisation. In a PPP contract, the government would continue to provide core services, while the private sector would provide the infrastructure and other non-core services. The core services include services such as health, education, welfare and suchlike. Non-core services include maintenance, cleaning, security and other services associated with the infrastructure. There is also a difference between PPPs and the traditional procurement method. According to Infrastructure Australia (2008), in the traditional method of procurement, the private sector knowledge and expertise are limited to the construction period, whereas in a PPP the private party's knowledge and expertise can extend to 20 years or more. Furthermore, the private party's risks are limited to defects during a liability period in a traditional procurement method, whereas in a PPP the private party's risks are wide-ranging and long-term.

The factors that may influence governments to enter into a PPP project include increased efficiency in public service delivery and national economic development plans (Kelman 2007). In a developing country such as South Africa, which has a severe backlog in physical infrastructure, PPPs can be an alternative in meeting the demand for infrastructure (Kelman 2007). Abedian (2012) estimates the monetary value of the infrastructure backlog to be at R3.5 trillion.

The National Development Plan (NDP) was adopted in 2010 by the South African government as its 20-year economic growth plan aimed at eradicating poverty and reducing inequality (KPMG South Africa 2014). The South African government identified the provision of infrastructure as one of the major economic drivers and, in line with the vision and objectives of the NDP, adopted the Infrastructure Plan in 2012 (Presidential Infrastructure Coordinating Commission [PICC] 2012). According to KPMG South Africa (2013), R11.8 trillion is required to reach NDP's target by 2030.

The South African government recognises the need to partner with the private sector in order to meet the infrastructural needs of the country. Trevor Manual, the former South African finance minister, argues that:

...the diverse interests of different sectors can, in fact, be
harnessed for the collective good. This is what PPPs are about.
The public gets better, more cost-effective services; while the
private sector gets new business opportunities. Both are in the
interests of the nation. (South African National Treasury Public
Private Partnerships Unit 2004)

In 2000, the South African National Treasury established the PPP Unit in its ministry in order to regulate PPPs in South Africa (South African National Treasury Public Private Partnerships Unit 2004). PPPs in South Africa are governed by Treasury Regulation 16 of the Public Finance Management Act, 1999, which defines a PPP as:

\footnotetext{
... a contract between a public sector and a private party, in which the private party assumes substantial financial, technical and operational risk in design, financing, building and operation of a project.
}

As of June, 2014, there were 69 PPP projects in preparation and registered, according to Regulation 16 of the National Treasury in South Africa (National Treasury PPP Unit 2004). This number is a drop in the ocean as compared to the number of PPPs completed in the UK. According to the House of Commons (2011), over 700 Public Finance Initiatives (PFIs) worth over $£ 60$ billion (at 2010 prices) had been contracted (2011). PFIs are 'a type of PPP used to fund major capital investments' (House of Commons 2008).

The South African PPP market is still in its infancy or stage 1. According to the United Nations (United Nations Economic Commission for Europe 2008), stage 1 is where there are a few PPP projects in the market. Given the South African government's commitment to infrastructure development in the country, the market for PPP is set to grow. South African quantity surveyors, therefore, need to take their rightful place in the PPP market in South Africa. 


\section{Research design}

The research philosophy adopted for this study was based on the following research question: What is the current and future possible role of quantity surveyors in PPPs in South Africa? The research strategies engaged were a questionnaire survey and a case study. Surveys are classified under the positivist philosophy, while case studies may fall under positivism or interpretivism (Saunders, Lewis \& Thornhill 2009).

The major deciding factors in the use of both survey and case study strategies were guided by the research question. According to Saunders et al. (2009), surveys are ideal in answering 'what', 'how much' and 'how many' questions. In order to answer the aforementioned research question, a survey using a self-administered questionnaire was used to determine the number of quantity surveyors involved in PPPs and the extent of their involvement in the PPPs. The case study, on the other hand, was mainly chosen for triangulation purposes. Together with the literature review, the case study provided important insights into what PPPs are in the real-life context in South Africa.

The data collection techniques chosen for the study were guided by the research objectives. As PPPs are still in their infancy in South Africa, there is no database that captures the number of quantity surveyors in South Africa who have participated in PPPs. Given the lack of such database, the best way to determine the number of quantity surveyors involved in PPPs was to collect this information via a questionnaire, and therefore quantitative data collection.

For the case study, personal and telephonic interviews were conducted, mainly to gain insight into what PPPs are in South Africa and how they are implemented. This is a qualitative data collection method. From the above, it is therefore clear that, for this study, a mixed-method research approach was used.

\section{Online survey}

The survey population for the online survey was made up of quantity surveyors in South Africa. As of 31 December 2014, there were 3813 quantity surveyors listed on the database of the South African Council for the Quantity Surveying Profession (SACQSP 2015). After obtaining approval from the Research Ethics Committee of the Faculty of Engineering, Built Environment and Information Technology, University of Pretoria, the survey was posted on the website of the ASAQS. There were 10900 subscribers to the ASAQS newsletter, with a link to their website, as of 23 October 2014.

In addition to the online survey posted on ASAQS website, the researcher sent 887 emails containing a link to the survey to potential participants (all quantity surveyors) to increase the number of potential respondents. This can be considered a purposive sample based on information from the ASASQ's centenary publication, the researcher's personal database as well as the Internet. The survey was created by the author through a survey software program called 'Survey Monkey', which is user-friendly and allows participants to respond anonymously. 'Survey Monkey' was also used to capture and analyse the data. Data coding is performed automatically by the software, but the data were also double-checked by using Microsoft Excel. After the data had been verified by a statistician, the results were presented in bar charts to give theoretical meaning to the results.

From a total of 80 survey respondents, 71 were used for data analysis. Some responses were incomplete, while the information provided on others was incorrect. The 71 respondents, therefore, constituted the sample that was used to determine the level of participation of quantity surveyors in PPPs in South Africa.

A general rule of thumb for selecting a sample size is that the bigger the sample size, the more accurate the prediction (Kumar 2014). However, Flick (2011) is of the view that a smaller sample is acceptable only if it avoids gross generalisation. A sample of 70 was therefore considered sufficient for the purposes of the research.

The online survey questionnaire was divided into five sections. Section 1 solicited background information from the respondents, that is, size of the firm, the geographic location, the economic sector of the firm and the career experience of the respondents, in order to determine whether all quantity surveying firms participate in a PPP or whether it is only the big, private firms in the more economically developed provinces.

Section 2 of the questionnaire focused on the respondents' level of knowledge regarding PPPs and participation in PPPs. The respondents who had participated in PPPs were required to provide further information regarding the party they were providing services for, quantity surveying services they provided, phases of PPP they worked in and the distinctive quantity surveying skills they applied in the project. The main objective of Section 2 was to determine the quantity surveyors' current role and future possible role.

Section 3 of the questionnaire was intended to determine the extent of quantity surveyors' involvement in non-traditional roles to establish whether most quantity surveyors prefer their traditional roles over their other non-traditional roles.

Section 4 solicited perceptions regarding the education and competency of a quantity surveyor by using the Likert scale. According to Nkado (2000), there is a link between knowledge and competency. The main objective of Section 4 was to determine whether quantity surveyors' education and training has provided them with the skills and competencies that can be transferred to non-traditional roles.

Section 5 of the questionnaire solicited information regarding respondents' additional education to their initial training. The aim of Section 5 was to determine whether further 
education determined if quantity surveyors who had further training in non-traditional role were likely to undertake work in their non-traditional roles functions.

\section{Case study design}

As stated previously, a case study design was also used to determine the extent of the quantity surveyors' participation in PPPs in South Africa. The greatest advantage of a case study is that it verifies its findings from multiple sources of evidence (Blumberg, Cooper \& Schindler 2008).

The participants in the case study interviews were representatives from both the public party and the private party. The quantity surveyor for the transaction advisor (the person responsible for the feasibility study) participated in the research through a questionnaire similar to the online survey. The questions posed were both semi-structured and unstructured questions, as both types of questions are recommended by Blumberg et al. (2008) for a case study.

Data were obtained through personal and telephonic interviews. Consideration was given to time, cost, preference and convenience when selecting the type of method to be used in data collection. Qualitative data analysis was used to analyse the case study results. By using narrative conceptualisation, the data collected from the interviews were arranged into themes and then presented in tabular format.

\section{Results}

\section{The survey results}

\section{The results}

\section{Background information:}

- The majority of quantity surveyors (49\%) are from firms that do not employ more than five people and are employed in private quantity surveying firms (75\%). Of the respondents who have worked in PPPs, an overwhelming majority $(86 \%)$ were from firms that employed $1-20$ people and $71 \%$ of them were employed in private firms.

- Most quantity surveying firms are located in Gauteng (31\%). The majority (38\%) of quantity surveyors who have participated in PPPs were based in Gauteng, followed by KwaZulu-Natal (KZN) at $24 \%$.

- Of the respondents, $46 \%$ have 25 years of experience or more. Of the quantity surveyors who have participated in PPPs, 29\% had over 25 years of experience. The overall combined majority of $58 \%$ had a career experience of $1-15$ years.

\section{Level of knowledge and participation in PPPs:}

- Although $70 \%$ of the respondents stated that they are familiar with PPPs, the majority (49\%) of respondents acknowledged that their familiarity with PPPs is only average. The majority $(70 \%)$ of respondents have also never participated in a PPP project. Forty-four per cent of the respondents, who have participated in PPPs, rate their familiarity to PPPs as average. Sixty-two per cent of those who have participated in PPP were consulting for the public entity.

- Estimating is the most offered service (76\%) in PPPs. Other quantity surveying services, such as feasibility studies and financial control, also received high scores, averaging a percentage of $61 \%$. Respondents who participated in a PPP were more involved in the procurement $(85 \%)$ phase of the project. The overall results, however, show that no PPP phase is more suitable for quantity surveyors than another. Other phases, such as inception and feasibility, scored an average of $60 \%$. Forecasting and budgeting $(81 \%)$ are the most distinctive quantity surveying skills offered by most respondents who have participated in a PPP.

\section{Traditional and non-traditional role of quantity surveyors:}

- Project management as a non-traditional quantity surveying role is the most likely $(76 \%)$ non-traditional role to be offered by quantity surveyors. Most respondents (59\%), however, seldom undertook work in non-traditional quantity surveying roles, with only $41 \%$ of the respondents indicating that they regularly undertook work in nontraditional quantity surveying roles. There were no respondents who never undertook work in non-traditional quantity surveying roles. Lack of enough market (71\%) was cited as the main reason why respondents seldom undertook work in non-traditional roles.

\section{Quantity surveyors' perceptions regarding their education} and competency:

- Initial education and training is regarded by the majority (75\%) of the respondents as the reason for their competency in the traditional role of quantity surveyor. Of the respondents who have worked in PPPs, 60\% believe that their education has adequately prepared them for their traditional role. Of the respondents, 59\% either absolutely agreed (15\%) or somewhat agreed (44\%) that their training has also adequately prepared them for the non-traditional role.

- For respondents who have worked in PPPs, $24 \%$ absolutely agree and 38\% somewhat agree that their education has adequately prepared them for their nontraditional role. Only $43 \%$ of the respondents absolutely or somewhat agree that tertiary education has adequately incorporated courses on non-traditional roles in their training. Of the respondents, $28 \%$ are unsure, $31 \%$ disagree somewhat and $4 \%$ absolutely disagree. Of the respondents who have worked in PPPs, $62 \%$ either absolutely agree $(14 \%)$ or somewhat agree $(48 \%)$ that tertiary education has adequately incorporated courses on non-traditional roles.

- The majority of respondents (52\%) somewhat agree (43\%) or absolutely agree $(9 \%)$ that their competency in the nontraditional role can be attributed to their initial education from a tertiary institution. Of the respondents who have worked in a PPP project, $43 \%$ somewhat agree and 14\% 
absolutely agree that their competency in the nontraditional role can be attributed to their initial education from a tertiary institution.

- Of the respondents, 35\% somewhat agree or absolutely agree (32\%) that they feel just as comfortable in their nontraditional role as they do in their traditional role. For respondents who have worked in a PPP, 70\% somewhat agree (35\%) or absolutely agree (35\%) that they feel just as comfortable in their non-traditional role as they do in their traditional role.

- Of the respondents, $86 \%$ somewhat agree $(54 \%)$ or absolutely agree (32\%) that their education and training, knowledge and skills could easily be transferred to their non-traditional role. Of the respondents who have worked in a PPP, $81 \%$ somewhat agreed $(48 \%)$ or absolutely agreed (33\%) that their education and training, knowledge and skills were transferable to non-traditional roles; however, the majority of respondents somewhat agree (46\%) and absolutely agree (26\%) that they need additional training to participate in non-traditional roles.

- Of the respondents who have worked in PPPs, 50\% somewhat agree and 25\% absolutely agree that they need additional training to participate in non-traditional roles. Of the respondents, $43 \%$ absolutely agree and $31 \%$ somewhat agree that non-traditional roles should be offered as certificate courses by tertiary or other institutions. For respondents who have worked in PPPs, $50 \%$ absolutely agree and $25 \%$ somewhat agree that nontraditional roles should be offered as certificate courses by tertiary or other institutions.

\section{Quantity surveyors' further education:}

- Sixty-six per cent of the respondents do not have formal training in non-traditional role as compared to $75 \%$ of the respondents who have participated in PPPs.

- The majority of the respondents have formal training in project management $(75 \%)$, while $80 \%$ of the respondents who have worked in PPPs have formal training in project management. According to most respondents (53\%), the most useful training for their organisation would be in project management.

- For respondents who have worked in PPPs, valuation (61\%) was rated by the majority as the most useful training their organisation could use. Project management, quantity surveying in engineering, facilities management and property development were all tied at second.

\section{Case study results}

\section{The results}

\section{Interview with the public sector:}

- Prior to the PPP project, there were no quantity surveyors employed within the Department of Education. Quantity surveyors in the PPP were expected to determine the capital cost and the project risk.

- The services provided by the quantity surveyor were satisfactory and are highly recommended in future projects. Apart from partaking in the PPP, the quantity surveyor provided additional services on an ad hoc basis.

- The public party regards quantity surveyors as the indispensable part of the team; however, the project officer had limited knowledge about the services provided by the quantity surveyor prior to the project and had never engaged the services of a quantity surveyor before.

- As a result of the services provided by the quantity surveyor in the project, the department (public sector) is now engaging the services of quantity surveyors in their various infrastructure projects.

\section{Interview with the transaction advisor:}

- Quantity surveyors formed part of the transaction advisor's team. The phases in which the quantity surveyors were involved in included feasibility studies and procurement.

- During the development, delivery and closure phases, the quantity surveyors were expected to check variation cost on an ad hoc basis. According to the transaction advisor, the quantity surveyor's service on the project was excellent.

- Prior to the PPP project, the transaction advisor had worked with a quantity surveyor before. The transaction advisor who was interviewed is an engineer by profession and has a good understanding of the role of quantity surveyors in the built environment.

- As quantity surveyors' services are secured, there were no additional services provided by the quantity surveyor. The transaction advisor regarded quantity surveyors as vital members of the team and thus recommends them for future projects.

\section{Questionnaire with the private party:}

- The quantity surveyor (the respondent) in this PPP project has over 25 years of quantity surveying experience. The respondent works for a private quantity surveying firm that employs over 100 people. The firm is based in Gauteng. The list of his clientele includes the public party, the private party (special purpose vehicle), transaction advisor, the consortium contractor, the lender (financial institutions) and the operators 'sub-contractor'.

- The respondent has worked in numerous PPP projects in his career and therefore has a high familiarity with PPP projects. Feasibility and viability studies, estimating and cost advice, financial control and whole-life cycle are the main quantity surveying services that are provided by the respondent in PPP projects.

- Quantity surveying skills were used by the respondent in all the six phases of a PPP project. The main distinctive quantity surveying skills that were applied include measurement, contractual advice and arrangement, forecasting and budgeting, analysis, cost planning, cost controlling and whole-life cycle costing.

- The private quantity surveyor provides the following non-traditional role functions: dispute resolution, property development, facilities management and project management. 
- The respondent somewhat agrees that his education and training has adequately prepared him for the traditional quantity surveying role. The quantity surveyor absolutely disagrees that his education and training has adequately prepared him for the non-traditional quantity surveying role.

- The respondent was unsure of the statement that tertiary education adequately incorporated courses on nontraditional roles in their training, and he absolutely disagrees that his competency in the non-traditional role is largely because of his initial education from a tertiary institution.

- The respondent's response to the statement that he feels just as comfortable in the non-traditional role as in the traditional role was that he absolutely agrees. The respondent also absolutely agrees that quantity surveying education and training, knowledge and skills can easily be transferred to the non-traditional role.

- The respondent somewhat agrees with the statement that quantity surveyors need additional training to competently provide services in the non-traditional role, and the respondent also somewhat agrees with the statement that non-traditional roles should be offered as certificate courses by tertiary institutions or other institutions.

- The respondent indicated that there should be some formal training in non-traditional quantity surveying role. This training is in leadership and management, facilities management and PPP courses.

\section{Discussion of the results Discussion of the results of the survey}

\section{Discussion of the results: Background information}

From the background information provided by the respondents, an inference can be drawn that the size of the firm and career longevity do not determine participation in PPPs. The result, however, indicates that quantity surveyors who are most likely to participate in PPPs are from private firms in more economically active provinces. Gauteng and KZN are the two top contributors to South Africa's gross domestic product (GDP). In 2012, Gauteng contributed 34.7\% and KZN contributed 15.8\% (Statistics South Africa 2013).

\section{Discussion of the results: Quantity surveyors' level of knowledge and participation in PPPs}

The results indicate that most quantity surveyors are familiar with PPPs even though the degree of their familiarity is average. The majority of quantity surveyors who have participated in PPPs also rated their familiarity to PPPs as average. Familiarity to PPPs is therefore not a determinant of participation in a PPP.

Section 2 of the survey questionnaire yielded other interesting points. Firstly, even though estimating was more likely to be offered in a PPP project, generally, there is no particular quantity surveying service that is more suitable for a PPP than any other. The same conclusion can be drawn regarding the most distinctive quantity surveying skill suitable for a PPP, although forecasting and budgeting are more likely to be offered. Secondly, most quantity surveyors are more likely to be engaged in the procurement phase of the project but their skills are not limited to the procurement phase only. Lastly, the public party is most likely to engage the services of a quantity surveyor in a PPP. In South Africa, PPPs are usually initiated by the public party and it is, therefore, expected that the public party will require the services of a quantity surveyor especially at the initial phases of the project to determine the capital cost of the project. The capital cost of the project is important in determining whether a project should pursue the traditional route or go through a PPP procurement process.

\section{Discussion of the results: Traditional and non-traditional role of quantity surveyors}

Most quantity surveyors seldom undertook work in the nontraditional roles of the quantity surveyor as a result of the perceived lack of market. It is, therefore, the market that determines participation in the non-traditional roles and not preference to the traditional role. This conclusion was supported by the fact that the results indicated that many quantity surveyors have been involved in other nontraditional roles in their careers - with the majority of them being involved in project management.

\section{Discussion of the results: Quantity surveyors' perception regarding their education and competency}

The majority of quantity surveyors' perception of their education is that it has adequately prepared them for their traditional roles and non-traditional roles. They also believe that their skills can easily be transferred to their nontraditional roles. The results, however, highlight that education influences competency and that training in their non-traditional roles would be of great benefit in their performance in their non-traditional roles.

\section{Discussion of the results: Further education}

The majority of quantity surveyors, including those who have worked in PPPs, do not have additional training in their non-traditional roles. The majority of those quantity surveyors who have additional training in non-traditional roles have their training in project management. Therefore, a conclusion can be drawn that quantity surveyors are likely to participate in project management as a result of market influences or their education, or both.

\section{Discussion of the results of the case study}

The public party, the transaction advisor and the private party regard quantity surveyors as important role players in a PPP project. Quantity surveyors' services and skills were highly recommended for future PPP projects by all the interviewees. From these results, two inferences can be drawn. Firstly, quantity surveying skills can be transferred to their non-traditional roles. It is also plausible, even though not all conclusive, that the reason for the quantity surveyors' limited participation is perceived lack of market as the major 
stakeholders are of the view that quantity surveyors' skills are indispensable in a PPP project.

From the results of the questionnaire of the quantity surveyors who have participated in a PPP project, a few conclusions can be drawn. Additional education in a non-traditional role is beneficial but not necessary for participation in a PPP or any other non-traditional quantity surveying role.

\section{Conclusion}

The results from both the survey and the case study highlight that quantity surveyors currently play a limited role in PPPs, although they possess the necessary skills required in a PPP project. The major reason for their limited participation is not the lack of adequate education or preference to the traditional role but the perceived lack of the market and the economy.

If the South African government's NDPs come to fruition, it is likely that PPPs will be engaged in the delivery of many infrastructure projects. It can thus be concluded that quantity surveyors' market share in the PPPs will likely increase in the future.

\section{Acknowledgements Competing interests}

The authors declare that they have no financial or personal relationships which may have inappropriately influenced them in writing this article.

\section{Authors' contributions}

Both the authors have contributed equally to the writing of this article.

\section{References}

Abedian, I., 2012, South African infrastructure drive: Beware of inappropriate financia structuring, Political Economy Note, Pan African Investment and Research Services, Johannesburg.

Ajalekoko, J.O., 2004, 'Branding the quantity surveying profession to meet the challenges of built environment', paper presented at the Fourth World Congress for the International Cost Engineering Council, Cape Town, 17-21st April.

Association of South African Quantity Surveyors (ASAQS), 2009, A century of quantity surveying in South Africa, Chris van Rensburg Publications (Pty) Ltd., Johannesburg.
Association of South African Quantity Surveyors (ASAQS), 2014, The history of quantity surveying, viewed 19 April 2014, from http://www.asaqs.co.za/?page=history

Bible, 2009, True identity. The Bible for women: New International Version, Zondervan Bibles, MI.

Blumberg, B., Cooper, D.R. \& Schindler, P.S., 2008, Business research methods, McGraw-Hill Higher Education, London.

Cartlidge, D., 2006, New aspects of quantity surveying practice, Elsevier ButterworthHeinemann, Oxford.

Department of Public Works, 1997, White paper on creating an enabling environment for reconstruction, growth and development in the construction industry, Government Printer, Pretoria.

Drake, B., 1995, Construction economics in the single European market for the Committee of European Construction Economists, Spon, London.

Flick, U., 2011, A beginner's guide to doing a research project, Sage, London.

House of Commons, 2008, Private finance initiative - Its rationale and accounting treatment, viewed 6 May 2015, from http://www.parliament.uk/documents/ upload/0807pfi.pdf

House of Commons, 2011, Private finance initiative 17th report of session 2010-2012, The Stationary Office Limited, London.

Infrastructure Australia, 2008, National public private partnership guidelines: Overview, Australian Government, Infrastructure Australia.

Kelman, S., 2007, Discussion paper on procurement issues in South Africa that effect growth and development, Harvard University, Cambridge.

KPMG South Africa, 2013, Planned infrastructure expenditure and the NDP: Mind the gap, KPMG Services (Proprietary) Limited, Johannesburg.

KPMG South Africa, 2014, 'Unpacking the infrastructure development plan', Infrastructure, 6 March, viewed 5 December 2014, from http://www.sablog. kpmg.co.za/2014/03/unpacking-national-infrastructure-development-plan/

Kumar, R., 2014, Research methodology: A step-by-step-guide for beginners, Sage, Los Angeles, CA.

Mouraviev, N. \& Kakabadse, N.K., 2012, 'Conceptualising public-private partnerships: A critical appraisal of approaches to meanings and forms', Society and Business Review 7(3), 260-278. https://doi.org/10.1108/17465681211271332

National Treasury Public Private Partnerships (PPP) Unit, 2004, Standardised publicprivate partnerships provisions, viewed 1 April 2014, from http://www.ppp.gov. za/Legal\%20Aspects/Standardised $\% 20$ PPP\%20Provinsions/National\%20 Treasury $\% 20$ PPP $\% 2$ Practice $\% 2$ Note $\% 20$ No $\% 201 \% 20$ of $\% 202004 ; \% 20$ Standardised $\% 20$ PPP\%20Provisions; $\% 2$ First $\% 2$ Issue;\%2011\%20March $\% 20$ 2004_1.pdf

Nkado, R.N., 2000, Competencies of professional quantity surveyors in a developing economy, University of Port Elizabeth, Port Elizabeth.

Presidential Infrastructure Coordinating Commission (PICC), 2012, A summary of the infrastructure plan, viewed 07 December 2014, from http://www.economic.gov. $\mathrm{za} / \mathrm{communications/media/press-releases-2012/196-summary-of-south-african-}$ infrastructure-plan/download

Saunders, M., Lewis, P. \& Thornhill, A., 2009, Research methods for business students, Pearson, Essex.

South Africa, 2001, 'Public Finance Management Act No.1 of 1999', Government Gazette No 22141: 1-50, viewed 7 March 2014, from http://www.treasury.gov.za/ legislation/PFMA/act.pdf

South African Council for the Quantity Surveying Profession (SACQSP), 2015, Email communication with the author on 19 January 2015, Johannesburg, viewed n.d., from $h t t p: / / s a c q s p . o r g . z a$

South African National Treasury Public Private Partnerships Unit, 2004, Public private partnership manual: National Treasury PPP practice notes issued in terms of the Public Finance Management Act, National Treasury Public Private Partnerships Unit [CD], Pretoria.

Statistics South Africa, 2013, Statistical release P0441: Gross domestic product November 2013, Statistics South Africa, Pretoria.

United Nations Economic Commission for Europe, 2008, Guidebook on promoting good governance in public private partnerships, Geneva, United Nations. 